\title{
Estrogen Receptor-Beta Gene Polymorphism in women with Breast Cancer at the Imam Khomeini Hospital Complex, Iran
}

\author{
Sakineh Abbasi
}

\begin{abstract}
ER-alpha and ER-beta genes have been proven to play a significant role in breast cancer. Epidemiologic studies have revealed that age-incidence patterns of breast cancer in Middle East differ from those in the Western countries. Two selected coding regions in the ER- $\beta$ gene (exons 3 and 7) were scanned in Iranian women with breast cancer (150) and in healthy individuals (147). PCR single-strand conformation polymorphism was performed. A site of silent single nucleotide polymorphism was found only on exon 7. The SNP was found only in breast cancer patients $(5.7 \%)\left(x^{2}=\right.$ $17.122, P=0.01)$. Codon 392 (C1176G) of allele 1 was found to have direct association with the occurrence of lymph node metastasis. Our data suggest that ER- $\beta$ polymorphism in exon 7 codon 392 (C1176G) is correlated with various aspects of breast cancer and lymph node metastasis in our group of patients.
\end{abstract}

\section{Introduction}

Breast cancer is the most prevalent cancer among women in most parts of the world, including Iran. Geographical variations in incidence and mortality rates of breast cancer suggest that the known risk factors for breast cancer may vary in different parts of the world and that environmental factors may be of greater importance than genetic factors [1]. For instance, in Iran it has been shown that, even after adjusting for age, young women are at relatively higher risk for developing breast cancer than are their Western counterparts $[2,3]$.

It is known that breast cancer typically arises in luminal epithelial cells of the mammary gland $[4,5]$. These cells contain estrogen receptors (ERs), which respond to ovarian estrogen in normal mammary gland development. How estrogens stimulate cell growth is not fully understood, but it is known that estrogen activation of ERs results in transcription of various genes that are involved in cellular proliferation

Only a small fraction $(<5 \%)$ of women diagnosed with breast cancer have a clear hereditary predisposition [6-8], and of these, about one half have predisposing mutations in BRCA1, BRCA2, PTEN, TP53, or other known cancer

* Correspondence: sakineh4612004@yahoo.com

1 Department of Medical Laboratory Sciences, Faculty of Allied Medicine, Tehran University of Medical Sciences, Iran

Full list of author information is available at the end of the article predisposing genes. However, twin studies indicate that the heritability of breast cancer is about 30\% [9], suggesting that genes other than the well-mapped regions act as modifiers of breast cancer risk. Although it is likely that low penetrance as well as high penetrance genes may be involved in the etiology, it remains unclear which genomic regions and which biochemical functions or signal transduction pathways account for the additional heritability of breast cancer incidence or progression.

Epidemiologic evidence suggests that estrogen plays a crucial role in most breast cancers in women who have both early menarche and late menopause. Obesity is also associated with breast cancer risk; estrogen synthesis in adipose tissue is proposed to account for this increase in risk. There is data on the involvement of estrogen receptor in the molecular processes implicated in the rise of breast cancer incidence [10-16].

ER- $\alpha$ polymorphic variants have been associated with breast cancer risk [17-25] in Caucasians. Furthermore, ER- $\alpha$ has been studied extensively, but supporting evidence is required for proving the involvement of ER- $\beta$ in breast cancer [26-33]. Currently, the literature contains sparse information regarding ER- $\beta$ gene expression, mutation frequency, and allelic variation in breast cancer. Thus, the present study aimed to identify candidate steroid hormone receptor gene variants in randomly 
selected regions (exon 3 and exon 7) of the ER- $\beta$ gene that might be associated with risk of breast cancer. It is our long-term objective to establish a genetic polymorphism database for the ER- $\beta$ encoding regions of the Iranian (Asian-Caucasian) genome, and to test for any correlation between ER- $\beta$ polymorphism and various clinically observable features of breast cancer in Iranian women.

\section{Methods \\ Study population}

A case-control study was conducted from April 2004 to January 2008 in Tehran, Iran. The breast cancer patients $(\boldsymbol{n}=150$; mean age $47.49 \pm 11.43$ years) were newly diagnosed and mostly living in Tehran. They were entered into the study if they had a confirmed pathological breast cancer diagnosis at the Imam Khomeini Hospital Complex (a large teaching and general hospital in the central district of Tehran) and were referred to the several clinics of the Cancer Institute of the hospital. The control group $(\boldsymbol{n}=147$; median age $40.75 \pm 10.54$ years $)$ included healthy women neither with any history of breast cancer nor any other neoplastic diseases, and none of their relatives had a history of breast cancer diagnosed at the same clinics [34]. Women with hysterectomy and artificial menopause, or women exposed to any kind of radiation and chemotherapy in their lifetime were excluded from the study. All participants in our study provided written informed consent to participate before entering the present study.

Demographical and risk factor data were collected using a short structured questionnaire, including information on age, weight, height, race, religion, marital status, number of pregnancies and children, age at first child birth, average lactation term, family history of breast cancer (first-degree relatives), age at menarche, age at marriage, menopausal status, and age at menopause, $\mathrm{ABO}$ and Rhesus blood groups, race, age at onset, lymph node metastases, cancer stage at the time of testing and ER expression in breast cancer tissue. A protocol to collect and store blood samples for future genomic tests had been approved by the institutional review board. Peripheral blood was collected and genotyping analysis was performed.

\section{Screening for ER- $\beta$ variants by single strand conformation polymorphism analysis}

In order to identify any change in the two selected exons (exons 3 and exon 7) of ER- $\beta$, PCR and SSCP was performed. Genomic DNA was extracted from blood leukocytes using the DNG ${ }^{\text {mix}}-$ Plus extraction kit (Cinnagen Inc, Tehran, Iran) in accordance with the manufacturer's instructions. Specific set of primers for ER- $\beta$ gene exons 3 and 7 were designed by primer 3 (v. 0.4.0) software (Table $1)$.
PCR was performed through 30 cycles with the following steps: denaturation $30 \mathrm{sec}$ at $95^{\circ} \mathrm{C}$, annealing $30 \mathrm{sec}$ at $58^{\circ} \mathrm{C}$ and elongation 40 seconds at $72^{\circ} \mathrm{C}$. The SSCP was carried out on $12 \%$ polyacrylamide gel (29:1 Acrylamide/ Bisacrylamide), with $200 \mathrm{~V}$, for $20 \mathrm{~h}$ at $16^{\circ} \mathrm{C}$. After electrophoresis, silver nitrate staining was used for visualizing the bands. To identify and confirm the exhibited irregular pattern in SSCP, PCR samples demonstrating varying band shift patterns as the result of first sequencing with forward primer, were re-purified on agarose gel using a DNA Extraction Kit (Fermentas \# K0153, Germany) and directly sequenced by big dye Terminator V3.1 Cycle Sequencing kit protocol, (Applied Biosystem Kit, Microgen Co., USA), on a sequencer ABI 3130XL (16capillaries).

The PCR product purification method was used in order to confirm sequencing by reverse primer. The PCR products were purified using QIAquick PCR purification Kit (50) (QIAGEN, USA).

\section{Statistical analysis}

$X^{2}$ testing was employed to assess the influence of polymorphism status on features of breast cancer. Unconditional logistic regression analysis was performed using SPSS software (version 11.5 for Windows XP; SPSS Inc., Cary, NC, USA) to calculate odds ratios (ORs) with 95\% confidence intervals (CIs) and to examine the predictive effect of each factor on risk for breast cancer. $P<0.05$ was considered as statistically significant.

\section{Results}

In this study, 150 breast cancer patients and 147 healthy women without family history of breast cancer were selected as controls. In exon \#3, we did not find novel mutation or any synonymous SNP in the Iranian population. Exon \#7 revealed no novel mutations but a silent SNP in codon 392 (Leu 392 Leu), rs1256054 (dbSNP128), a conversion of nucleotide C to G (C 1176 G) was observed. Both CTC and CTG code for Leucine amino acid. The observed numbers of individuals with different genotypes showed that this SNP fitted the Hardy-Weinberg equilibrium for both control and patient groups $(\boldsymbol{P}>0.05)$. The codon 392 polymorphism was found only in patients. Statistically significant frequency was achieved; $8.7 \%$ for the CG genotype, and $1.3 \%$ for the GG genotype in comparison to $90.0 \% \mathrm{CC}$ in the normal genotype $\left(X^{2}=4.769, P=0.029\right)$ (Table 2$)$.

Among all risk factors, only race and $\mathrm{ABO}$ blood groups were statistically significant $(P<0.05)$ between cases and controls. Women from the Fars province (near the southern part of Iran) revealed a significant genotypic distribution frequency only within CG heterozygote patients $\left(X^{2}=9.11, P=0.003\right)$. When the ABO blood groups were considered, A and B blood groups showed 
Table 1: Primers selected for Exons \#3 and \#7 of Gene ER- $\beta$

\begin{tabular}{clll}
\hline Polymorphism site & Melting temperature $\left({ }^{\circ} \mathbf{C}\right)$ & Oligonucleotic sequences & Sequence size \\
& & & 151 \\
Exon 3 & 59.23 & Primers for PCR reaction & \\
& 59.86 & F TTGCTCCCTAGAGAGACACTGA & \\
Exon 7 & & R CTCACACGACCAGACTCCA & 156 \\
& 60.04 & Primers for PCR reaction & \\
\hline
\end{tabular}

statistically significant frequencies between cases and controls $\left(X^{2}=4.920, P=0.027\right.$, and $X^{2}=5.108, P=0.024$ respectively) (Table 3 ).

Among breast cancer patients, 70.1\% revealed a firstdegree family history of breast cancer with CG (52.6\%) or GG (10.5\%) genotype and $2.3 \%$ without family history of breast cancer with CG genotype. This difference was statistically significant $\left(X^{2}=27.645, P=0.001\right)$. In breast cancer patients with LN metastasis, the genotypic distribution frequency of codon 392 showed statistically significant difference with frequencies of $30.4 \%$ for CG and $8.7 \%$ for GG, in comparison with breast cancer patients without LN metastases $(4.7 \%)\left(X^{2}=17.314, P=\right.$ 0.001) (Table 4).

The frequency of allele $392 \mathrm{G}$ was significantly $\left(\chi^{2}=\right.$ 4.583, $P=0.032$ ) higher in cancer patients with the age at menarche being 12 years old or below $(9.2 \%)$ than those reaching menarche above 12 years of age (3.3\%). The frequency of allele $392 \mathrm{G}$ was significantly higher in cancer patients with a first-degree family history (36.8\%) than in those without a family history $(1.1 \%$, with a difference of $35.7 \%$ ), in comparison with the frequency of allele $392 \mathrm{C}$ which is significantly lower in cancer patients with a firstdegree family history than in those without a family history $\left(X^{2}=78.847, P=0.001\right.$ ) (Table 5$)$. Moreover, the allelic frequency of $392 \mathrm{C}$ was significantly higher in cancer patients with LN metastases $(23.9 \%)$ than in those without $\mathrm{LN}$ metastases $(2.4 \%)$ with a difference of $21.5 \%$, in comparison with the frequency of allele $392 \mathrm{C}$ which was significantly lower in cancer patients with LN metas- tases (76.1\%) than in those without LN metastases (97.6\%) $\left(\chi^{2}=33.838, P=0.001\right)$ (Table 5).

Significant correlation was found for first-degree relatives with family history of breast cancer and LN metastasis, as indicated by the ORs presented in Table 6. In regards to the criterion of breast cancer, genotype frequencies exhibited a significantly different distribution in cases and controls $(\boldsymbol{P}=0.029)$. The estimated risk was higher in cases $(47.9 \%)$ than in controls $(52.1 \%)$ in individuals with the normal CC, genotype. Nevertheless, CG or GG genotype in codon 392 was observed only in breast cancer patients.

Furthermore, genotype frequencies exhibited different distributions in the presence or absence of a first-degree relative family history of breast cancer, with statistical significance for codon $392(\boldsymbol{P}=0.001)$ and LN metastasis. The estimated risk was very much lower for both CG individuals with family history of breast cancer LN metastasis than controls (OR 0.016 and 0099 respectively, 95\% CI). Moreover, GG genotype was only observed in individuals with family history of breast cancer and LN metastasis (Table 6).

\section{Discussion}

ER- $\beta$ is one of the most important players in the mechanism of estrogen action and is found in many tissues, including the central nervous system, cardiovascular system, immune system, urogenital tract, gastrointestinal tract, kidneys and lungs. It is an obvious candidate gene to harbor allelic variants which predispose to breast can-

Table 2: Genotypic distribution frequencies of codon 392 in exon 7 of estrogen receptor- $\beta$ gene in the study population: breast caner versus control groups

\begin{tabular}{|c|c|c|c|c|c|c|c|c|c|}
\hline \multirow[t]{2}{*}{ Codon 392} & \multirow{2}{*}{$\begin{array}{l}\text { Normala } \\
\text { Frequency }\end{array}$} & \multirow[b]{2}{*}{ Percent } & \multicolumn{2}{|c|}{ Heterozygote $^{b}$} & \multicolumn{2}{|c|}{ Homozygotec } & \multicolumn{2}{|c|}{ Total } & \multirow[t]{2}{*}{ Test result } \\
\hline & & & Frequency & Percent & Frequency & Percent & Frequency & Percent & \\
\hline Case & 135 & 90.0 & 13 & 8.7 & 2 & 1.3 & 150 & 100 & $\begin{array}{l}X^{2}=4.769 \\
P=0.029\end{array}$ \\
\hline Control & 147 & 100 & - & - & - & - & 147 & 100 & \\
\hline Total & 282 & 94.9 & 13 & 4.4 & 2 & 0.7 & 297 & 100 & \\
\hline
\end{tabular}

a Genotype normal or 329CC, CTC/CTC, b Genotype heterozygote or 329CG, CTC/CTG, c Genotype homozygote or 329GG, CTG/CTG 
Table 3: Genotypic distribution frequencies of codon 392 in exon 7 of estrogen receptor- $\beta$ gene and major risk factors in study population: breast cancers, versus control groups

\begin{tabular}{|c|c|c|c|c|c|}
\hline Characteristic & Group & $00^{\mathrm{a}} \%$ & $01^{\mathrm{b}} \%$ & $11 \mathrm{c} \%$ & Test resul \\
\hline \multicolumn{6}{|c|}{ Age at menarche(years) } \\
\hline \multirow[t]{3}{*}{$</=12$} & Case & 83.3 & 15.0 & 1.7 & $\begin{array}{l}X^{2}=1.887 \\
P=0.169\end{array}$ \\
\hline & control & 100 & - & - & \\
\hline & total & 89.6 & 9.4 & 1.0 & \\
\hline \multirow[t]{3}{*}{$>12$} & Case & 94.4 & 4.4 & 1.1 & $\begin{array}{c}X^{2}=2.229 \\
P=0.135\end{array}$ \\
\hline & control & 100 & - & - & \\
\hline & total & 97.5 & 2.0 & 0.5 & \\
\hline \multicolumn{6}{|l|}{ Race } \\
\hline \multirow[t]{3}{*}{ Arab \& Armani } & Case & 100 & - & - & - \\
\hline & control & - & - & - & \\
\hline & total & 100 & - & - & \\
\hline \multirow[t]{3}{*}{ Fars } & Case & 90.0 & 10.0 & - & $\begin{array}{l}X^{2}=9.11 \\
P=0.003\end{array}$ \\
\hline & control & 100 & - & - & \\
\hline & total & 95.9 & 4.1 & - & \\
\hline \multirow[t]{3}{*}{ Lor \& Kurdish } & Case & 83.3 & 11.1 & 5.6 & $\begin{array}{l}X^{2}=0.697 \\
P=0.404\end{array}$ \\
\hline & control & 100 & - & - & \\
\hline & total & 88.9 & 7.4 & 3.7 & \\
\hline \multirow[t]{3}{*}{ Turkish } & Case & 93.5 & 4.3 & 2.2 & $\begin{array}{l}X^{2}=1.17 \\
P=0.279\end{array}$ \\
\hline & control & 100 & - & - & \\
\hline & total & 96.5 & 2.4 & 1.1 & \\
\hline \multirow[t]{3}{*}{ Gilaki \& Mazani } & Case & 87.0 & 13.0 & - & $\begin{array}{l}X^{2}=1.527 \\
P=0.217\end{array}$ \\
\hline & control & 100 & - & - & \\
\hline & total & 91.2 & 8.8 & - & \\
\hline \multicolumn{6}{|c|}{ ABO blood Groups } \\
\hline \multirow[t]{3}{*}{ A } & Case & 88.9 & 11.1 & - & $\begin{array}{c}X^{2}=4.920 \\
P=0.027\end{array}$ \\
\hline & control & 100 & - & - & \\
\hline & total & 95.7 & 4.3 & - & \\
\hline \multirow[t]{3}{*}{ B } & Case & 85.7 & 14.3 & - & $\begin{array}{l}X^{2}=5.106 \\
P=0.024\end{array}$ \\
\hline & control & 100 & - & - & \\
\hline & total & 95.9 & 4.1 & - & \\
\hline \multirow[t]{3}{*}{$A B$} & Case & 100 & - & - & - \\
\hline & control & 100 & - & - & \\
\hline & total & 100 & - & - & \\
\hline \multirow[t]{3}{*}{$\mathrm{O}$} & Case & 90.3 & 7.8 & 1.9 & $\begin{array}{c}X^{2}=1.884 \\
P=0.17\end{array}$ \\
\hline & control & 100 & - & - & \\
\hline & total & 93.6 & 5.1 & 1.3 & \\
\hline
\end{tabular}


Table 4: Genotypic distribution frequencies of codon 392 in exon 7 of estrogen receptor- $\beta$ gene and selected demographic characteristics and major risk factors

\begin{tabular}{|c|c|c|c|c|}
\hline Characteristic & $00^{2} \%$ & 01b\% & $11 \mathrm{c} \%$ & Test result \\
\hline \multicolumn{5}{|l|}{ BMI $\left(\mathbf{k g} / \mathrm{m}^{2}\right)$} \\
\hline$</=18.5$ & 80.0 & 20.0 & - & $\begin{array}{c}X^{2}=0.144 \\
P=0.705\end{array}$ \\
\hline $18.5-24.9$ & 91.2 & 7.0 & 1.8 & \\
\hline $25-29.9$ & 90.9 & 9.1 & - & \\
\hline$>30$ & 87.9 & 9.1 & 3.0 & \\
\hline Total & 90.0 & 8.7 & 1.3 & \\
\hline \multicolumn{5}{|c|}{ Onset age of breast cancer (years) } \\
\hline$</=40$ & 91.7 & 8.3 & - & $\begin{array}{c}X^{2}=0.959 \\
P=0.328\end{array}$ \\
\hline$>40$ & 89.2 & 8.8 & 2.0 & \\
\hline Total & 90.0 & 8.7 & 1.3 & \\
\hline \multicolumn{5}{|c|}{ Family history of breast cancer } \\
\hline First-degree family affected & 36.8 & 52.6 & 10.5 & $\begin{array}{c}X^{2}=27.645 \\
P=0.001\end{array}$ \\
\hline Not affected & 97.7 & 2.3 & - & \\
\hline Total & 90 & 8.7 & 1.3 & \\
\hline \multicolumn{5}{|l|}{ Lymph node metastases } \\
\hline Yes & 60.9 & 30.4 & 8.7 & $\begin{array}{c}X^{2}=17.314 \\
P=0.001\end{array}$ \\
\hline No & 95.3 & 4.7 & - & \\
\hline Total & 90.0 & 8.7 & 1.3 & \\
\hline \multicolumn{5}{|c|}{ ER expression in breast cancer tissue } \\
\hline Positive & 80.0 & 15.0 & 5.0 & $\begin{array}{c}X^{2}=4.799 \\
P=0.028\end{array}$ \\
\hline Negative & 94.6 & 5.4 & - & \\
\hline Not studied & 88.9 & 11.1 & - & \\
\hline Total & 90.0 & 8.7 & 1.3 & \\
\hline
\end{tabular}

cer [35]. There are several studies examining the association of ER- $\beta$ variants and breast cancer risk in different populations [26-33], but these studies do not include rs1256054, with the exception to Zheng et al. [29]. This is the first study focusing on genetic variations of the ER$\beta$ gene in breast cancer patients in Iran. Two single nucleotide polymorphisms in the ER- $\alpha$ gene in relation to breast cancer were studied before $[24,40]$. In the present study, the SNPs are detected only in the cancer patient group, with significant $(P=0.029)$ increase of CG genotype $(8.7 \%)$ as compared with the GG genotype $(1.3 \%)$, suggesting the CG genotype confers risk for development of breast cancer (Table 2). Furthermore, the frequency of the CG genotype was found to be significantly $(P<0.005)$ increased in the Fars race and also in both blood groups
$\mathrm{A}$ and $\mathrm{B}$ in comparison with the other risk factors $(10 \%$, $11.1 \%$ and $14.3 \%$ respectively) indicating that both CG genotype and mentioned characteristics might have influence in developing breast cancer (Table 3). SNPs in different regions of the ER- $\beta$ gene previously reported suggest the associate of ER- $\beta$ polymorphisms with breast cancer, anorexia nervosa, Parkinson and ovulatory dysfunction [26-28,36-39].

Increased frequency of CG genotype was also observed in patients with first-degree relative family history of breast cancer as compared to patients with no family history of breast cancer (a difference of 50.3\%) in compare with GG genotype (a difference of 10.5\%) suggesting that CG genotype might influence development of familial breast cancer more than the GG genotype. When LN sta- 
Table 5: Allelic frequencies of estrogen receptor- $\beta$ exon 7, codon 392 (CTC/CTG) in the study population: breast cancer cases versus control groups and breast cancer cases in the presence versus the absence of major risk factors

\begin{tabular}{|c|c|c|c|}
\hline \multirow[b]{2}{*}{ Characteristic } & & \multicolumn{2}{|c|}{ ER- $\beta$ Alleles } \\
\hline & & $\mathbf{C a}^{\mathrm{a}}$ & $\mathbf{G}^{\mathbf{b}}$ \\
\hline \multicolumn{4}{|l|}{ Breast cancer } \\
\hline Case & $(n=150)$ & $283(94.3 \%)$ & $17(5.7 \%)$ \\
\hline \multirow[t]{2}{*}{ Control } & $(n=147)$ & $294(100 \%)$ & - \\
\hline & & \multicolumn{2}{|c|}{$X^{2}=17.122, P=0.001$} \\
\hline \multicolumn{4}{|l|}{ Age at menarche(years) } \\
\hline$</=12$ & $(n=60)$ & 109(90.8\%) & $11(9.2 \%)$ \\
\hline \multirow[t]{2}{*}{$>12$} & $(n=90)$ & $174(96.7 \%)$ & $6(3.3 \%)$ \\
\hline & & \multicolumn{2}{|c|}{$X^{2}=4.583, P=0.032$} \\
\hline \multicolumn{4}{|l|}{ Age at menopause (years) } \\
\hline$=<50$ & $(n=47)$ & $87(92.6 \%)$ & $7(7.4 \%)$ \\
\hline \multirow[t]{2}{*}{$>50$} & $(n=12)$ & $24(100 \%)$ & - \\
\hline & & \multicolumn{2}{|c|}{$X^{2}=1.884, P=0.17$} \\
\hline \multicolumn{4}{|l|}{ ABO blood groups } \\
\hline$A$ & $(n=27)$ & $51(94.4 \%)$ & $3(5.6 \%)$ \\
\hline B & $(n=14)$ & $26(92.9 \%)$ & $2(7.1 \%)$ \\
\hline$A B$ & $(n=6)$ & $12(100 \%)$ & - \\
\hline \multirow[t]{2}{*}{$\mathrm{O}$} & $(n=103)$ & 194(94.2\%) & $12(5.8 \%)$ \\
\hline & & \multicolumn{2}{|c|}{$X^{2}=0.058, P=0.81$} \\
\hline \multicolumn{4}{|l|}{ Race } \\
\hline Arab \& Armani & $(n=3)$ & $6(100 \%)$ & - \\
\hline Fars & $(n=60)$ & $114(95.0 \%)$ & $6(5.0 \%)$ \\
\hline Lor \& Kurdish & $(n=18)$ & $32(88.9 \%)$ & $4(11.1 \%)$ \\
\hline Turkish & $(n=46)$ & $88(95.7 \%)$ & $4(4.3 \%)$ \\
\hline \multirow[t]{2}{*}{ Gilaki \& Mazani } & $(n=23)$ & $43(93.5 \%)$ & $3(6.5 \%)$ \\
\hline & & \multicolumn{2}{|c|}{$X^{2}=0.05, P=0.822$} \\
\hline \multicolumn{4}{|c|}{ Family history of breast cancer } \\
\hline First-degree family affected & $(n=19)$ & $24(63.2 \%)$ & $14(36.8 \%)$ \\
\hline \multirow[t]{2}{*}{ Not affected } & $(n=131)$ & $259(98.9 \%)$ & $3(1.1 \%)$ \\
\hline & & \multicolumn{2}{|c|}{$X^{2}=78.847, P=0.001$} \\
\hline \multicolumn{4}{|l|}{ Lymph node metastases } \\
\hline Yes & $(n=23)$ & $35(76.1 \%)$ & $11(23.9 \%)$ \\
\hline \multirow[t]{2}{*}{ No } & $(n=127)$ & $248(97.6 \%)$ & $6(2.4 \%)$ \\
\hline & & \multicolumn{2}{|c|}{$X^{2}=33.838, P=0.001$} \\
\hline \multicolumn{4}{|c|}{ ER expression in breast cancer tissue } \\
\hline Positive & $(n=40)$ & $70(87.5 \%)$ & $10(12.5 \%)$ \\
\hline Negative & $(n=92)$ & 179(97.3\%) & $5(2.7 \%)$ \\
\hline \multirow[t]{2}{*}{ Not studied } & $(n=18)$ & $34(94.4 \%)$ & $2(5.6 \%)$ \\
\hline & & \multicolumn{2}{|c|}{$X^{2}=5.161, P=0.023$} \\
\hline
\end{tabular}

a Allele 392C, CTC, b Allele 392G, CTG 
Table 6: Estimated risk for selected demographic characteristic and major risk factors with estrogen receptor- $\beta$ exon 7 , codon 392 in different genotypes

\begin{tabular}{|c|c|c|c|c|}
\hline Breast cancer & $\begin{array}{c}\text { Yes } \\
n=150\end{array}$ & $\begin{array}{c}\text { No } \\
n=147\end{array}$ & Pvalue & OR $(95 \% \mathrm{CI})$ \\
\hline Normala & $135(47.9 \%)$ & $147(52.1 \%)$ & 0.029 & 1.0 (reference) \\
\hline Heterozygoteb & $13(100 \%)$ & - & & - \\
\hline Homozygotec & $2(100 \%)$ & - & & - \\
\hline Age at menarche (years) & $</=12$ & $>12$ & $P$ value & OR $(95 \% \mathrm{CI})$ \\
\hline Genotype & $n=60$ & $\mathbf{n}=\mathbf{9 0}$ & & \\
\hline Normal & $50(37.0 \%)$ & $85(63 \%)$ & 0.437 & 1.0(reference) \\
\hline Heterozygote & $9(69.2 \%)$ & $4(30.8 \%)$ & & $0.261(0.077-0.893)$ \\
\hline Homozygote & $1(50 \%)$ & $1(50 \%)$ & & $0.588(0.036-9.613)$ \\
\hline First- degree family history of breast cancer & Affected & Not affected & $P$ value & OR $(95 \% \mathrm{CI})$ \\
\hline Genotype & $n=19$ & $n=131$ & & \\
\hline Normal & $7(5.2 \%)$ & $128(94.8 \%)$ & 0.001 & 1.0(reference) \\
\hline Heterozygote & $10(76.9 \%)$ & $3(23.1 \%)$ & & $0.016(0.004-0.073)$ \\
\hline Homozygote & $2(100 \%)$ & - & & - \\
\hline Lymph node metastases & Yes & No & $P$ value & OR (95\% CI) \\
\hline Genotype & $\mathbf{n}=\mathbf{2 3}$ & $n=127$ & & \\
\hline Normal & $14(10.4 \%)$ & $121(89.6 \%)$ & 0.001 & 1.0(reference) \\
\hline Heterozygote & $7(53.8 \%)$ & $6(46.2 \%)$ & & $0.099(0.029-0.337)$ \\
\hline Homozygote & $2(100 \%)$ & - & & - \\
\hline
\end{tabular}

a Genotype normal or 329CC, CTC/CTC, b Genotype heterozygote or 329CG, CTC/CTG, c Genotype homozygote or 329GG, CTG/CTG

tus of the patients were considered again, the frequency of CG genotype was $21.7 \%$ greater in patients with $\mathrm{LN}$ metastasis than those without LN metastasis in comparison with the frequency of GG genotype (a difference of 8.7\%), indicating that CG genotype might associate with LN metastasis in Iranian population (Table 4).

Some studies such as investigations conducted in Shanghai [29], Sweden [30] and the US [31] found no overall statistically significant differences between the allelic frequencies of cases and controls. However, a number of investigations conducted in different populations such as Finland [32], India [26], Germany [33] and Japan [37] have found a statistically significant difference between the allelic frequencies of cases and controls as we found here in our study. The results strengthened the association between codon 392 polymorphism and breast cancer development. Furthermore, we found allelic frequency of $G$ to be significantly much higher in cases with the history of breast cancer in first-degree relatives when compared with non-familial cases (with difference of $35.7 \%$ ). An increased frequency of allele $G$ was also observed in patient with LN metastasis as compared with patients without LN metastasis (with differences of $21.5 \%)(P=0.001)$ which suggest that the presence of allele $\mathrm{G}$ might be predictive of both familial breast cancer and bad progression of the disease (Table 5). In terms of practical utility, the relation between codon 392 variant and probability of LN metastasis deserves further consideration as a clinical indicator during pre-surgical evaluation. Such a test is of interest because lymphatic invasion is associated with local recurrence and disease progression, and LN metastasis is considered an important indicator when deciding whether chemotherapy should be given [41-44].

Nevertheless, the link between silent polymorphisms and phenotypes is unclear. One of the possibilities might be that the silent polymorphism is in linkage with another genetic mutation that directly affects breast cancer phenotype. The other possibility might be that the nucleotide composition at the silent polymorphic site could alter the gene expression level of ER- $\beta$, thus leading to LN metastasis in breast cancer. 
ER- $\beta$ genotypes were compared with selected clinical breast cancer features, including age at menarche, family history of breast cancer, and LN metastasis. Significant correlation $(P=0.001)$ was found for family history of breast cancer and LN metastasis, as indicated by the ORs presented in Table 6. The estimated risk was much lower for individuals with family history of breast cancer and patients with LN metastasis who were heterozygote in codon 392 (OR 0.016 and OR 0.099 respectively with 95\% CI) than for the corresponding controls. This indicates that codon 392 polymorphism does not influence breast cancer risk

Taken together, codon 392 SNP might influence development of familial breast cancer and LN metastasis but it cannot be considered as a breast cancer risk factor.

\section{Conclusion}

We have identified codon 392 CTC/CTG polymorphism to be associated with an increased risk of familial breast cancer with LN metastasis. Moreover, CG heterozygosity increases in familial breast cancer and LN metastasis. However, our results imply that although the SNP examined in this study does not play a causal role in the etiology of breast cancer, the ER- $\beta$ gene variants may be involved in breast cancer susceptibility. This was the first systematic association study in ER- $\beta$ variants with various aspects of breast cancer in Iran. ER- $\beta$ genotype, as determined during pre-surgical evaluation, might present a surrogate marker for predicting breast cancer lymph node metastasis. Further analysis is needed to elucidate the role of ER- $\beta$ polymorphisms in breast cancer susceptibility. Continuation of this study on other regions of the ER- $\beta$ gene will provide additional insight into the biology and complex etiology of breast carcinogenesis.

\section{Abbreviations \\ BMI: Body Mass Index; Cl: confidence interval; ESR: estrogen receptor; LN: lymph node; OR: odd ratio; PCR: polymerase chain reaction; Rh: Rhesus blood group system; SNP: single nucleotide polymorphism; SSCP: single-strand con- formational \\ Competing interests \\ The author declares that they have no competing interests. \\ Acknowledgements \\ This research has been supported by Tehran University of Medical Sciences \& Health Services grant \# 6165. The author would like to thank Ms. Elham Faraz- andeh and Ms. Maasomeh Jafari Eftekhar from Central Clinic1, Imam Khomeini Hospital complex, who made blood samples and clinical information available from patients. I sincerely appreciate and acknowledge to Dr. Mina Haji Faraj Tabrizi for her brilliant English editings. \\ The author also, wish to thank the anonymous referees of the Journal for their} helpful comments on a previous version of the paper.

\section{Author Details}

Department of Medical Laboratory Sciences, Faculty of Allied Medicine, Tehran University of Medical Sciences, Iran

Received: 9 January 2010 Accepted: 7 July 2010

Published: 7 July 2010

\section{References}

1. McPherson K, Steel C, Dixon J: Breast cancer-epidemiology, risk factors, and genetics. BMJ 2000, 321:624-628

2. Harirchi I, Ebrahimi M, Zamani N, Jarvandi S, Montazeri A: Breast cancer in Iran: a review of 903 case records. Public Health 2000, 114:143-145.

3. Mousavi SM, Montazeri A, Mohagheghi MA, Jarrahi AM, Harirchi I, Najafi M, Ebrahimi M: Breast Cancer in Iran: An Epidemiological Review. Breast J 2007, 13(4):383-391

4. Anderson E, Clarke R, Howell A: Estrogen responsiveness and control of normal human breast proliferation. J Mammary Gland Biol Neoplasia 1998, 3:23-35.

5. Anderson $\mathrm{E}$ : The role of oestrogen and progesterone receptors in human mammary development and tumorigenesis. Breast Cancer Res 2002, 4:197-201

6. Newman B, Mu H, Butler L, Millikan R, Moorman P, King M: Frequency of breast cancer attributable to BRCA1 in a population-based series of American women. JAMA 1998, 279:915-921.

7. Vehmanen P, Friedman L, Eerola H, Sarantaus L, Pyrhönen S, Ponder B, Muhonen T, Nevanlinna $\mathrm{H}$ : A low proportion of BRCA2 mutations in Finnish breast cancer families. Am J Hum Genet 1997, 60:1050-1058.

8. Whittemore A, Gong G, Itnyre J: Prevalence and contribution of BRCA1 mutations in breast cancer and ovarian cancer: results from three U.S. population-based case-control studies of ovarian cancer. Am J Hum Genet 1997, 60:496-504

9. Lichtenstein P, Holm NV, Verkasalo PK, Iliadou A, Kaprio J, Koskenvuo M, Pukkala E, Skytthe A, Hemminki K: Environmental and heritable factors in the causation of cancer-analyses of cohorts of twins from Sweden, Denmark, and Finland. N Engl J Med 2000, 343:78-85

10. de Jong M, Nolte I, te Meerman G, van der Graaf W, Oosterwijk Kleibeuker J, Schaapveld M, de Vries EG: Genes other than BRCA1 and BRCA2 involved in breast cancer susceptibility. J Med Genet 2002, 39:225-242

11. Jordan V: Selective estrogen receptor modulation: concept and consequences in cancer. Cancer Cell 2004, 5:207-213.

12. Hanstein B, Djahansouzi S, Dall $P$, Beckmann M, Bender $H$ : Insights into the molecular biology of the estrogen receptor define novel therapeutic targets for breast cancer. Eur J Endocrinol 2004, 150:243-255.

13. Tempfer C, Schneeberger C, Huber J: Applications of polymorphisms and pharmacogenomics in obstetrics and gynecology. Pharmacogenomics 2004, 5:57-65.

14. Lymberis S, Parhar P, Katsoulakis E, Formenti S: Pharmacogenomics and breast cancer. Pharmacogenomics 2004, 5:31-55.

15. Bland K, Copeland E: The breast: comprehensive management of benign and malignant disorders. 3rd edition. Saunders St. Louis; 2004

16. Kallel I, Rebai M, Khabir A, Farid NR, Rebaï A: Genetic Polymorphisms in the EGFR (R521K) and Estrogen Receptor (T594T) Genes, EGFR and ErbB-2 Protein Expression, and Breast Cancer Risk in Tunisia. J Biomed Biotechnol 2009, 2009:753683. Epub 2009 Jul 14

17. Iwase H, Greenman J, Barnes D, Hodgson S, Bobrow L, Mathew C: Sequence variants of the estrogen receptor (ER) gene found in breast cancer patients with ER negative and progesterone receptor positive tumors. Cancer Lett 1996, 108:179-184.

18. Curran J, Lea R, Rutherford S, Weinstein S, Griffiths L: Association of estrogen receptor and glucocorticoid receptor gene polymorphisms with sporadic breast cancer. Int J Cancer 2001, 95:271-275.

19. Vasconcelos A, Medeiros R, Veiga I, Pereira D, Carrilho S, Palmeira C Azevedo C, Lopes CS: Analysis of estrogen receptor polymorphism in codon 325 by PCR-SSCP in breast cancer: association with lymph node metastasis. Breast J 2002, 8:226-229.

20. Heldring N, Pike A, Andersson S, Matthews J, Cheng G, Hartman J, Tujague M, Strom A, Treuter E, Warner M, Gustafsson JA: Estrogen receptors: how do they signal and what are their targets. Physiol Rev 2007, 87:905-931.

21. Wang J, Higuchi R, Modugno F, Li J, Umblas N, Lee J, Lui LY, Ziv E, Tice JA Cummings SR, Rhees B: Estrogen receptor alpha haplotypes and breast cancer risk in older Caucasian women. Breast Cancer Res Treat 2007, 106:273-280.

22. Holst F, Stahl PR, Ruiz C, Hellwinkel O, Jehan Z, Wendland M, Lebeau A Terracciano L, Al-Kuraya K, Janicke F, Sauter G, Simon R: Estrogen receptor alpha (ESR1) gene amplification is frequent in breast cancer. Nat Genet 2007, 39:655-660. 
23. Roodi N, Bailey L, Kao W, Verrier C, Yee C, Dupont W: Estrogen receptor gene analysis in estrogen receptor-positive and receptor-negative primary breast cancer. J Nat/ Cancer Inst 1995, 87:446-451.

24. Azimi C, Abbasi S: Genetic polymorphisms in the estrogen receptor-a gene codon 325(CCCTCCG) and risk of breast cancer among Iranian women: a case control study. Med J Islamic Republic of Iran 2009, 23(2):75-82.

25. Srinivasan V, Spence DW, Pandi-Perumal SR, Trakht I, Esquifino Al, Cardinali DP, Maestroni GJ: Melatonin, environmental light, and breast cancer. Breast Cancer Res Treat 2008, 108(3):339-350.

26. Surekha D, Sailaja K, Nageswara Rao D, Raghunadharao D, Vishnupriya S: Oestrogen receptor beta (ER $\beta$ ) polymorphism and its influence on breast cancer risk. J Gent 2009, 88(2):261-266.

27. Iwasaki M, Hamada GS, Nishimoto IN, Netto MM, et al: Isoflavone, polymorphisms in estrogen receptor genes and breast cancer risk in case-control studies in Japanese, Japanese Brazilians and nonJapanese Brazilians. Official J Japan Cancer Assoc 2009, 100(5):927-933.

28. Rozenkranz K, Hinney A, Ziegler A, Herman H, Fichter M, et al.: Systematic mutation screening of estrogen receptor beta gene in probands of different weight extremes: identification of several genetic variants. $J$ Clin Endocrinol Metab 1998, 83:4524-4527.

29. Zheng S, Zheng W, Chang B, Shu X, Cai Q, Yu H, Dai Q, Xu J, Gao YT: Joint effect of estrogen receptor beta sequence variants and endogenous estrogen exposure on breast cancer risk in Chinese women. Cancer Res 2003, 63:7624-7629.

30. Maguire P, Margolin S, Skoglund J, Sun X, et al:: Gustafsson J. Estrogen Receptor Beta (ESR2) Polymorphisms in Familial and Sporadic Breast Cancer. Breast Cancer Res Treat 2005, 94(2):145-152

31. Cox DG, Philip Bretsky P, Peter Kraft P, Paul Pharoah P: Haplotypes of the Estrogen receptor beta (ESR2) gene and breast cancer risk. Int $J$ Cancer 2008, 122(2):387-392

32. Forsti A, Zhao C, Israelsson E, Dahlman-Wright K, Gustafsson JA, Hemminki $\mathrm{K}$ : Polymorphisms in the estrogen receptor beta gene and risk of breast cancer: no association. Breast Cancer Res Treat 2003(79):409-413.

33. Treeck O, Elemenler E, Kriener C, Horn F, Springwald A, Hartmann A, Ortmann O: Polymorphisms in the promoter region of ESR2 gene and breast cancer susceptibility. J Steroid Biochem Mol Biol 2009, 114(35):207-11.

34. Abbasi S: Polymorphisms in estrogen receptor -alpha and beta genes in breast cancer patients from Imam Khomeini Hospital. In [Ph.D thesis] Malaysia: Universiti Putra Malaysia; 2008.

35. Abbasi S, Ismail P, Othman F, Rosli R, Azimi C: Estrogen receptor-a (ESR1) gene, codon 594 (G3242A) polymorphism among Iranian women with breast cancer: a case control study. Asian J Scie Res 2009, 2(1):51-60.

36. Westberg L, Hakansson A, melke J, Shahabi HN, Nilsson S, et al: Association between the estrogen receptor beta gene and age at onset of Parkinson disease. Psychoneuroendocrinolgy 2004, 29:993-998.

37. Rosenkranz K, Hinney A, Ziegler A: Systematic mutation screening of the estrogen receptor beta gene in probands of different weight extremes: identification of several genetic variants. J Clin Endocrinol Metab 1998, 83:4524-4527

38. Sundarrajan C, Liao WX, Roy AC, Ng SC: Association between estrogen receptor-beta gene polymorphisms and ovulatory dysfunctions in patients with menstrual disorders. J Clin Endocrinol Metab 2001, 86:135-139.

39. Ogawa S, Hosoi T, Shiraki M, Orimo H, Emi M, Muramatsu M, Ouchi Y, Inoue S: Association of estrogen receptor beta gene polymorphism with bone mineral density. Biochem Biophys Res Commun 2000, 269:537-541.

40. KupierKupier GGJM, Carlsson B, Grandien K, Enmark E, Haggblad J, Nilsson S, Gustafsson J: Comparison of the ligand binding specificity and transcript tissue distribution of estrogen receptors $a$ and $\beta$. Endocrinology 1997, 3:863-870

41. Fisher E, Anderson S, Redmond C, Fisher B: Pathologic findings from the National Surgical Adjuvant Breast Project protocol B-06. 10-yea pathologic and clinical prognostic discriminants. Cancer 1993, 71:2507-2514

42. Henson DE, Ries L, Freedman LS, Carriaga M: Relationship among outcome, stage of disease, and histologic grade for 22,616 cases of breast cancer. The basis for a prognostic index. Cancer 1991, 68:2142-2149.
43. Canavese G, Catturich A, Vecchio C, Tomei D, Gipponi M, Bruzzi P: Prognostic role of lymph-node level involvement in patients undergoing axillary dissection for breast cancer. Eur J Surg Oncol 1998, 24:104-109.

44. Goldhirsch A, Wood W, Senn H, Glick J, Gelber R: Meeting highlights: international consensus panel on the treatment of primary breast cancer. J Natl Cancer Inst 1995, 87:1441-1445.

\section{Pre-publication history}

The pre-publication history for this paper can be accessed here: http://www.biomedcentral.com/1471-2350/11/109/prepub

doi: 10.1186/1471-2350-11-109

Cite this article as: Abbasi, Estrogen Receptor-Beta Gene Polymorphism in women with Breast Cancer at the Imam Khomeini Hospital Complex, Iran BMC Medical Genetics 2010, 11:109

\section{Submit your next manuscript to BioMed Central and take full advantage of:}

- Convenient online submission

- Thorough peer review

- No space constraints or color figure charges

- Immediate publication on acceptance

- Inclusion in PubMed, CAS, Scopus and Google Scholar

- Research which is freely available for redistribution

Submit your manuscript at www.biomedcentral.com/submit
C) Biomed Central 